\title{
An updated, annotated checklist of the marine mammals of Hong Kong
}

\author{
Thomas A. Jefferson ${ }^{1, *}$ and Samuel K. Hung ${ }^{2}$ \\ ${ }_{1}^{1}$ Southwest Fisheries Science Center, NOAA Fisheries, \\ 8604 La Jolla Shores Drive, La Jolla, CA 92038, USA, \\ e-mail: sclymene@aol.com \\ ${ }^{2}$ Hong Kong Cetacean Research Project, 12 Kak Tin \\ Kung Miu Village, Tai Wai, N.T., Hong Kong \\ ${ }^{*}$ Corresponding author
}

\begin{abstract}
Records of marine mammal strandings, sightings, and captures from the Hong Kong Special Administrative Region, People's Republic of China, were reviewed. A total of 16 species of cetaceans ( 1 baleen whale and 15 toothed whales, dolphins, and porpoises) have been confirmed to occur in Hong Kong. An additional two species of baleen whales have been reported, but cannot be confirmed at this time (in fact, we suspect that they are both misidentifications). Additional species may have occurred in Hong Kong in the past; however, the dugong and the gray whale have probably been extirpated from the area. Of those species found to be present in the area, only two are regularly observed in Hong Kong waters and are considered residents: the Indo-Pacific humpback dolphin (Sousa chinensis) and the finless porpoise (Neophocaena phocaenoides).
\end{abstract}

Keywords: Cetacea; distribution; Hong Kong SAR; Sirenia; strandings.

\section{Introduction}

Hong Kong is a small area that is designated as a Special Administrative Region within the People's Republic of China (Figure 1). It is embedded within Guangdong Province of China and is only approximately $1800 \mathrm{~km}^{2}$ in size. However, it has nearly $800 \mathrm{~km}$ of coastline, owing to the presence of many indented bays, channels and islands (Figure 1). Hong Kong lies along the northern shores of the South China Sea, a body of water with a diverse marine mammal fauna consisting of at least 31 species (Zhou et al. 1995, Wang et al. 2001, MacLeod et al. 2006, Wang and Yang 2006, Jefferson et al. in press). The territory is immediately to the east of the Pearl River Estuary, China's second largest, and its western waters are heavily influenced by this freshwater input. The eastern waters, on the other hand, are isolated from the influence of the river, and are much more oceanic in nature. Therefore, Hong Kong possesses a variety of cetacean habitats.
Since the initial note by Romer (1958) reporting strandings of three species of cetaceans in Hong Kong, nothing much had been written on the cetaceans of Hong Kong through the early 1990s. In the mid-1990s, Parsons et al. (1995) published an annotated checklist of cetaceans recorded from Hong Kong's territorial waters. They documented the confirmed or probable occurrence of 15 species of cetaceans for Hong Kong, based mostly on stranding records.

Since the early 1990s, there has been intensive research on the small cetaceans of Hong Kong, and the Indo-Pacific humpback dolphin (Sousa chinensis) and finless porpoise (Neophocaena phocaenoides) have been extensively studied (Parsons et al. 1995, 1999, Jefferson and Leatherwood 1997, Parsons 1997, 1998a,b,c, 1999, Parsons and Chan 1998, 2001, Porter 1998, Parsons and Jefferson 2000, Jefferson 2000, Jefferson et al. 2002a,b,c, 2005, 2006, Hung and Jefferson 2004, Jefferson and Hung 2004, Hung 2005a,b, 2006). The government-sponsored marine mammal stranding program, which had been in effect since 1973, was improved in 1993 and again in 1995. Since then a great deal has been learned about Hong Kong marine mammals.

This paper provides an updated and revised checklist of marine mammals (including sirenians) in Hong Kong through early 2007. It is based on published and unpublished literature, records and files from the stranding program [sponsored by the Agriculture, Fisheries and Conservation Department (AFCD), Hong Kong SAR Government], and records and data from the Hong Kong Cetacean Research Project (HKCRP) over the last 12 years. Museum records were also sought out and used to confirm species identifications, where appropriate.

\section{Species accounts}

Fin whale Balaenoptera physalus (Linnaeus, 1758)

Three species of the baleen whale family Balaenopteridae have been reported from Hong Kong, but whales of the genus Balaenoptera are notoriously easy to misidentify. The only record of a fin whale in Hong Kong is of a "stranding" (in fact the whale was trapped in the supports of a wharf and was subsequently shot) that occurred in Victoria Harbor on 12 April 1955 (Romer 1958). There is a photograph of the specimen published in Romer's paper, but unfortunately the angle of the photo is not good and it is not possible to confirm the identification (although it is clearly a member of the genus Balaenoptera). 


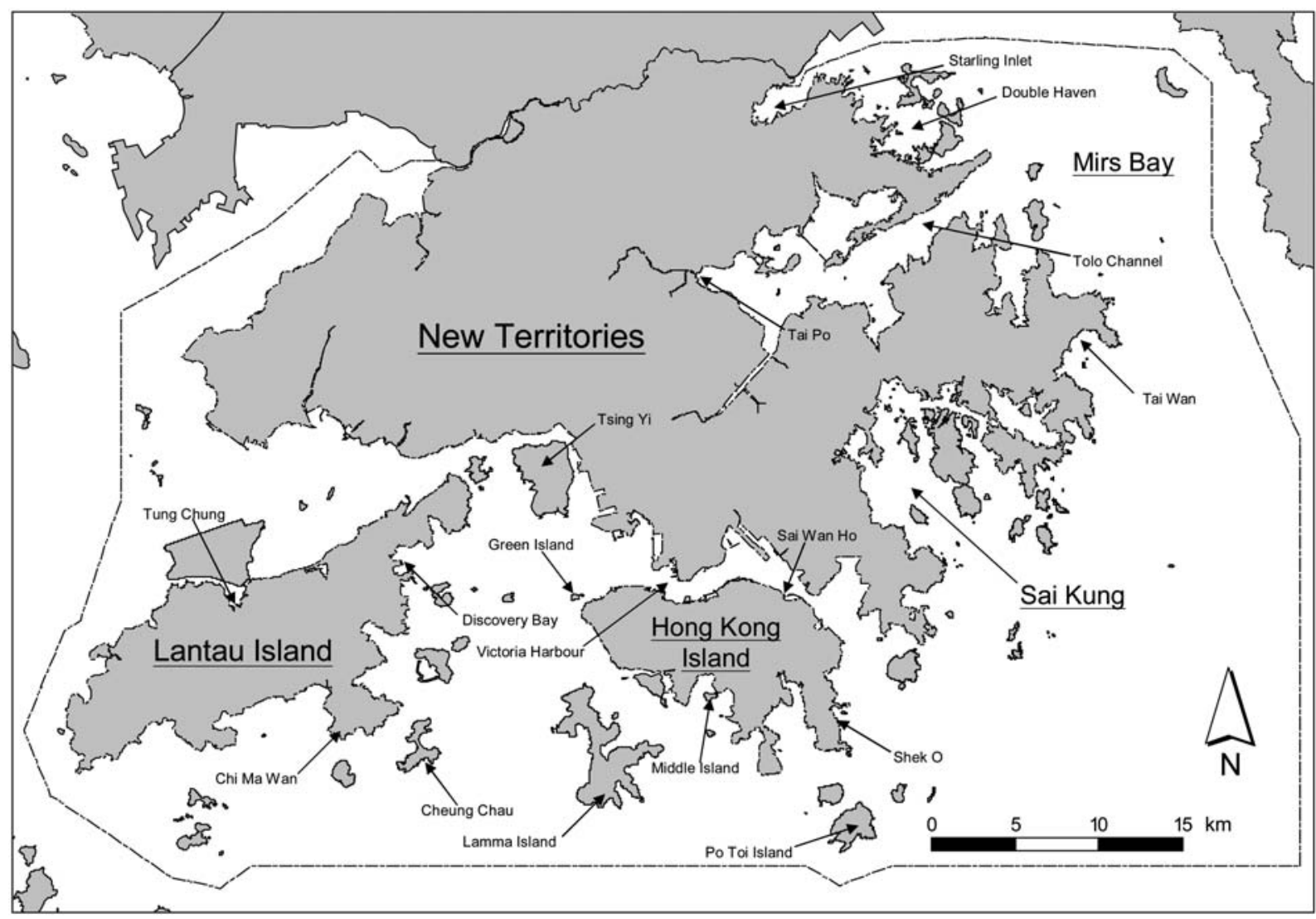

Figure 1 Map of Hong Kong showing major places names mentioned in the text.

Fortunately, this specimen (8.2 m, male) was mounted and placed on display at the University of Hong Kong, and then in the early 1990s was remounted and moved to an outdoor display at the University's Swire Institute of Marine Science, where it remains to this day (Morton et al. 1992). The specimen has been examined in detail, but the identification was inconclusive because of difficulty in taking measurements of the mounted specimen (T.K. Yamada, personal communication). We believe that this specimen may actually be a misidentified Bryde's whale, and we hope to confirm or refute this in the future.

\section{Bryde's whale Balaenoptera edeni/brydei Anderson, 1878/Olsen, 1913}

There are a number of confirmed stranding records of Bryde's whales from Hong Kong (Parsons et al. 1995, 1999, Hung and Jefferson 2001), along with several welldescribed second-hand sightings of what would appear to be this species in eastern waters (Jefferson, unpublished data). Although not actually within Hong Kong, an 11.9-m male Bryde's whale was live-stranded in Macau (approx. $25 \mathrm{~km}$ across the Pearl River Estuary, to the west of Hong Kong) on 30 August 2000 (Figure 2; Hung 2001). Two strandings of this species occurred in Hong Kong in the 1990s, the first at Cheung Chau in 1992 and the second at Tolo Harbor Channel in 1994 (Parsons et al. 1995). There have been five additional confirmed or probable strandings of this species in Hong Kong over the past several years (one in 2003, two in 2004 and three in 2005; Hung 2004, 2005a, 2006; see also Figure 2). In addition, a sighting of a specimen thought to be
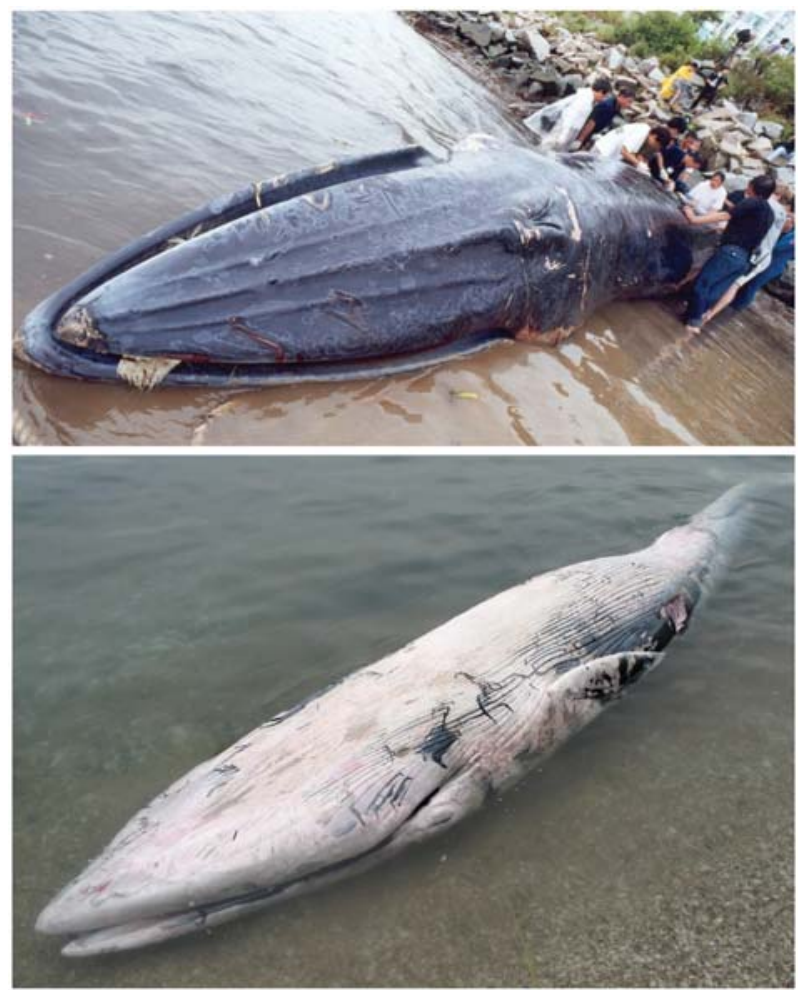

Figure 2 Bryde's whale stranded in Macau on 30 August 2000 (top) and Bryde's whale stranded in Hong Kong on 6 February 2005 (bottom). 
this species was made just offshore of Hong Kong in 1999/2000 (Torey 2000). These records, taken collectively, suggest that Bryde's whales may not be all that rare in and around Hong Kong.

The taxonomy of the Bryde's whale is in flux, and it is clear that there are at least two species, including a standard form and one or more small forms (Dizon et al. 1996, Reeves et al. 2004). The whales around Hong Kong appear to be of one of the smaller forms, and Sasaki et al. (2006) confirmed that specimens from Hong Kong waters examined by LeDuc and Dizon (2002) were what they called $B$. edeni (considered by them to be dwarf Bryde's whales).

We suggest that this may be the only species of baleen whale that occurs with any regularity in and around Hong Kong. In fact, all records of baleen whales from Hong Kong and its vicinity that can be identified with any confidence appear to be of Bryde's whales, and we suggest that most, if not all, reports of other species of the genus Balaenoptera in Hong Kong may actually be of this species.

\section{Common minke whale Balaenoptera acutorostrata Lacépéde, 1804}

Several reports of strandings and sightings of minke whales have been reported for Hong Kong (Morton et al. 1992, Parsons et al. 1995). However, most of these are older records that occurred in the 1970s and 1980s, and none of these records is supported by photos or descriptions of diagnostic characters. Our searches of AFCD stranding records did not reveal any such evidence either. Minke whales are very similar in size and external appearance to the dwarf form of the Bryde's whale, which appears to occur in Hong Kong with some regularity (see above). Most, if not all, of these records may be misidentifications of Bryde's whales.

We are therefore of the opinion that, while the minke whale may eventually be found to occur in Hong Kong, currently available evidence does not support this, and we consider this a species not yet confirmed there.

\section{Sperm whale Physeter macrocephalus Linnaeus, 1758}

There is an unconfirmed anecdotal report of a sperm whale in Hong Kong from the early 1990s (Parsons 1997). The first confirmed record of a sperm whale in Hong Kong occurred on 21 July 2003, when an 872-cm male was stranded alive at Tai Wan, north of Ham Tin (Hung 2004; Figure 3). The whale was discovered by campers early in the morning, and the stranding team arrived in the afternoon and found the animal in apparent distress. After some discussion, the animal was euthanized by AFCD veterinarians at 19:00 $\mathrm{h}$. No detailed necropsy was conducted, but blood, skin and blubber samples were collected the next morning. It was presumed that the animal suffered from kidney failure and pneumonia.

\section{Pygmy sperm whale Kogia breviceps (de Blainville, 1838)}

Both species of the family Kogiidae occur in the area. Four records of strandings of whales of the genus Kogia

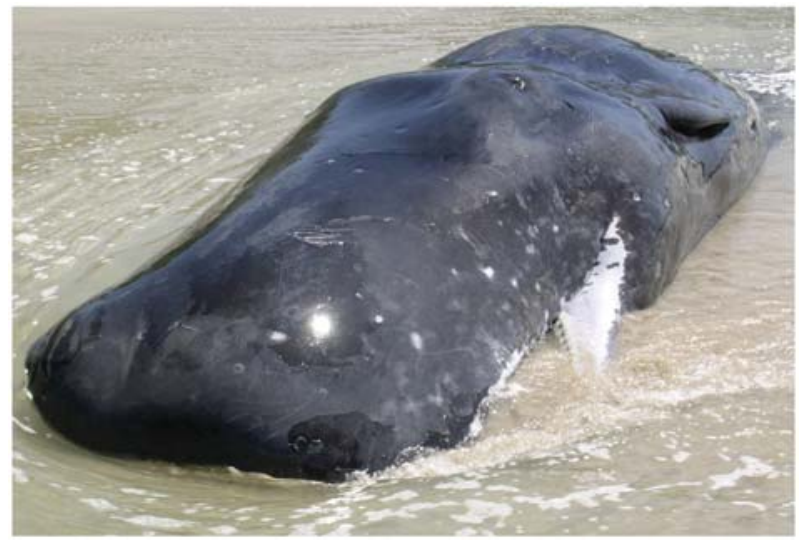

Figure 3 Sperm whale live-stranding that occurred on 21 July 2003.

in Hong Kong between 1986 and 1992 were all originally identified as Kogia breviceps (Parsons et al. 1995). However, detailed examination of the information available from these events, including skull morphology, indicates that only two can be confirmed to be $K$. breviceps (those occurring on 1 June 1986 and 3 October 1992 (the former was a live stranding; Porter and Morton 2003). In addition, a recent stranding of this species also occurred in Hong Kong on 4 January 2003, involving a 274-cm probable male (Hung 2003).

\section{Dwarf sperm whale Kogia sima Owen, 1866}

The dwarf sperm whale was not included in the previous checklist of Hong Kong cetaceans (Parsons et al. 1995). However, the Kogia stranding that occurred on 19 August 1991, previously identified as $K$. breviceps, has recently been demonstrated to be a specimen of $K$. sima, the first confirmed for Hong Kong (Porter and Morton 2003).

\section{False killer whale Pseudorca crassidens (Owen, 1846)}

Several species of the family Delphinidae occur in the South China Sea. Four strandings of the false killer whale have occurred in Hong Kong, one in 1983 (Parsons et al. 1995), one in 2000, one live-stranded on 19 August 2002 (Figure 4), and one in 2005 (Hung 2003, 2006). In addition, a sighting of "at least eight" false killer whales, supported by photos, was recorded on 10 March 1996 off Tsing $\mathrm{Yi}$ by a group of dolphin-watching tourists

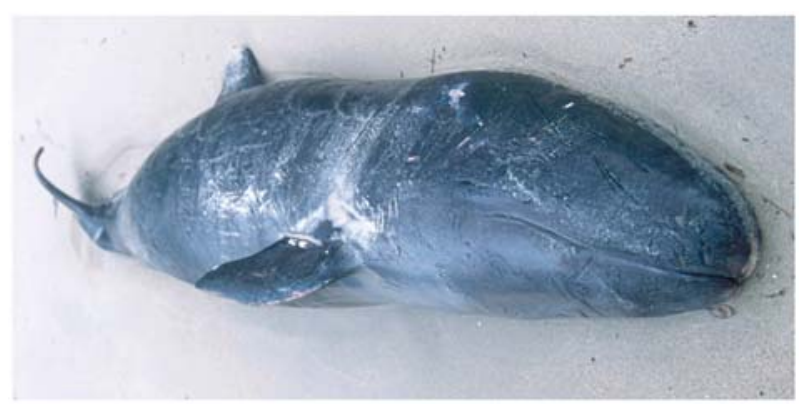

Figure 4 False killer whale live-stranding that occurred on 19 August 2002. 
(Hong Kong Dolphinwatch 1996, B. Leverett, personal communication).

\section{Indo-Pacific humpback dolphin Sousa chinensis (Osbeck, 1765)}

This is, without doubt, the most commonly observed species of marine mammal in Hong Kong (Parsons et al. 1995, Parsons 1998b, Jefferson 2000), where they are locally known as "Chinese white dolphins" or "pink dolphins". On average, approximately 10 strandings occur each year (Jefferson et al. 2006). Indo-Pacific humpback dolphins occur throughout the western waters of Hong Kong, which are influenced by freshwater input from the Pearl River (Parsons 1998b, Jefferson 2000). They are common in every month of the year in the waters north and west of Lantau Island. Abundance in Hong Kong's waters ranges from approximately 207 individuals in autumn to approximately 91 in spring (Jefferson et al. 2005). With the exception of occasional short-term wandering, they do not occur in Hong Kong's eastern waters east of Lamma Island. Although the species is commonly stranded in Hong Kong, live strandings are rare. The only recent known occurrence of a live stranding of this species was of a specimen on 8 August 2003, which later died at Ocean Park (Hung 2004, Jefferson et al. 2006).

\section{Rough-toothed dolphin Steno bredanensis (Lesson, 1828)}

Although Parsons et al. (1995) reported this species in Hong Kong based on a stranding record that occurred on 7 March 1982, re-examination of the files for this event provided no justification for the identification. However, there have been two strandings of this species in recent years. The first occurred on 8 May 2003, with a carcass found floating near Green Island. The second was a live stranding of a $214-\mathrm{cm}$ male that occurred on Lamma Island on 14 May 2004 (Hung 2005a,b; Figure 5). The latter specimen was taken to Ocean Park for rehabilitation, where it survived for 10 months. It finally died on 6 March 2005. Necropsy revealed several health problems, including evidence of brain and heart pathology, and possible gastric problems resulting from tube feeding.

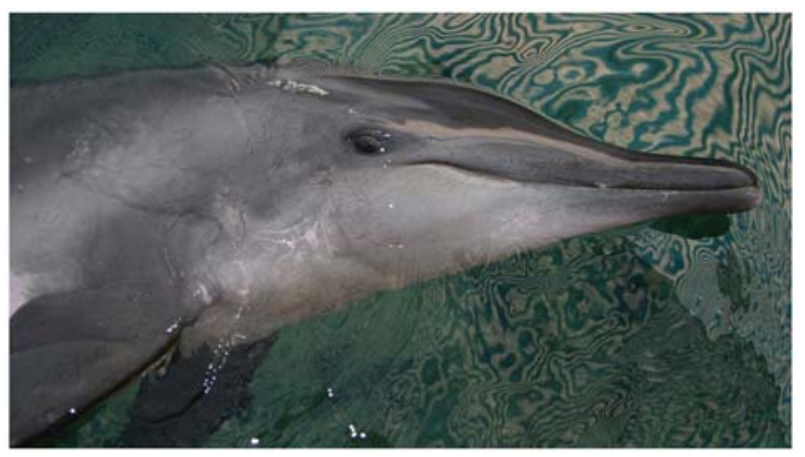

Figure 5 Rough-toothed dolphin in a rehabilitation pool at Ocean Park; the dolphin was live-stranded on 14 May 2004.
Risso's dolphin Grampus griseus (G. Cuvier, 1812)

Risso's dolphins have been stranded several times in Hong Kong. The first such event occurred in early June 1986 and involved the stranding of two to four individuals over a 5-day period in the same general area, near Tai Po in Tolo Harbor (Parsons et al. 1995). One of the animals was alive when discovered and was subsequently released at sea, but it was thought to be dead on 6 June. It seems likely that these animals were all part of a single protracted stranding event.

In September 1988, another Risso's dolphin carcass was stranded in Sai Kung (Parsons et al. 1995). The most recent event occurred on 27 January 2005 and involved a $272-\mathrm{cm}$ animal of unknown sex found near Discovery Bay on Lantau Island (Hung 2005a,b). Interestingly, a dolphin fitting the description of a Risso's was observed on 15 January near Discovery Bay and it seems likely that this was the same animal, or at least was part of the same group.

\section{Common bottlenose dolphin Tursiops truncatus (Montagu, 1821)}

This species appears to be the third most commonlystranded cetacean species in Hong Kong after the finless porpoise and humpback dolphin (Table 1). There have been at least eight individuals of what have been confirmed or thought to be common bottlenose dolphins stranded in Hong Kong since 1980 (Parsons et al. 1995, Parsons and Jefferson 2000, Barros et al. 2000, Parsons and Chan 2001, Hung 2003, AFCD records). This includes several live-strandings.

In addition, sightings of bottlenose dolphins (although these generally cannot always be confirmed to be T. truncatus vs. T. aduncus) have been recorded in the southern waters of Hong Kong over the past few years (Parsons et al. 1995, HKCRP unpublished data).

\section{Indo-Pacific bottlenose dolphin Tursiops aduncus (Ehrenberg, 1832)}

There is only a single confirmed record of this species in Hong Kong, a stranding of a $250-\mathrm{cm}$ female that occurred on 16 August 2004 (Hung 2005b; Figure 6). It should be noted that a few of the bottlenose dolphin records listed above may have been of this species, however. In addition, a sighting of what was probably this species occurred on 5 November 1998, near Po Toi Island (Figure 6; HKCRP unpublished data).

\section{Pantropical spotted dolphin Stenella attenuata (Gray, 1846)}

The first report of this species in Hong Kong, a stranding that occurred on 14 December 1987 (Parsons et al. 1995), was actually a misidentified Indo-Pacific humpback dolphin (based on re-examination of the photos and description). The first confirmed record of this species in Hong Kong occurred on 31 May 1996, a very badly decomposed specimen of ca. $187 \mathrm{~cm}$ found floating near Middle Island. The identification was made based on cranial features. A second stranding occurred on 29 June 2000 near Starling Inlet in Mirs Bay. 
Table 1 Records of bottlenose dolphins (Tursiops spp.) from Hong Kong.

\begin{tabular}{|c|c|c|c|c|c|c|}
\hline Date & Type of record & Species & Location & Sex & $\begin{array}{l}\text { Length } \\
(\mathrm{cm})\end{array}$ & Reference(s) \\
\hline Dec 1978 & Capture & Unidentified & Sai Kung & $\mathrm{U}$ & $\mathrm{U}$ & Hammond and Leatherwood 1984 \\
\hline 26 Nov 1980 & Stranding & Unidentified & Shek O & $\mathrm{U}$ & U & AFCD unpublished \\
\hline 20 Jul 1983 & Live stranding & Unidentified & Silvermine Bay & $\mathrm{U}$ & $\mathrm{U}$ & Parsons et al. 1995 \\
\hline 26 Mar 1985 & Live stranding $(n=2)$ & T. truncatus? & Deep Bay, NT & $\mathrm{U}$ & $\mathrm{U}$ & Parsons et al. 1995 \\
\hline 8 Aug 1986 & Stranding & Unidentified & Pak Lap Wan, Sai Kung & $U$ & U & Parsons et al. 1995 \\
\hline 23 Jun 1993 & Stranding & T. truncatus & Aberdeen Fish Market & $\mathrm{U}$ & 125 & AFCD unpublished \\
\hline 23 Apr 1994 & Unconfirmed stranding & Unidentified & Near Cape d'Aguilar & $\mathrm{U}$ & $U$ & Parsons et al. 1995 \\
\hline 7 May 1994 & Unconfirmed sighting & Unidentified & Near Cape d'Aguilar & $\mathrm{N} / \mathrm{A}$ & $\mathrm{N} / \mathrm{A}$ & Parsons et al. 1995 \\
\hline 25 Nov 1994 & Stranding & T. truncatus & Sui Sai Wan & $\mathrm{M}$ & 293 & $\begin{array}{l}\text { Parsons et al. 1995; } \\
\text { Parsons and Chan 2001; } \\
\text { Barros et al. 2000; } \\
\text { Parsons and Jefferson } 2000\end{array}$ \\
\hline 27 Nov 1994 & Unconfirmed stranding & Unidentified & Tai Long Wan & U & $U$ & Parsons et al. 1995 \\
\hline 4 Dec 1994 & Stranding & T. truncatus & Stonecutter's Island & $\mathrm{F}$ & 244 & $\begin{array}{l}\text { Barros et al. 2000; } \\
\text { Parsons and Chan 2001; } \\
\text { Parsons and Jefferson } 2000\end{array}$ \\
\hline 11 Dec 1994 & Unconfirmed stranding & Unidentified & Tolo Harbor & $\mathrm{U}$ & U & Parsons et al. 1995 \\
\hline 13 Jul 1995 & Stranding & T. truncatus & Aberdeen Harbor & $\mathrm{F}$ & 234 & $\begin{array}{l}\text { Barros et al. 2000; } \\
\text { Parsons and Chan 2001; } \\
\text { Parsons and Jefferson } 2000\end{array}$ \\
\hline 2 May 1997 & Stranding & T. truncatus & Tung Lung Chau & M & 294 & $\begin{array}{l}\text { Barros et al. 2000; } \\
\text { Parsons and Jefferson } 2000\end{array}$ \\
\hline 5 Nov 1998 & Sighting & T. aduncus? & Near Po Toi & $\mathrm{N} / \mathrm{A}$ & N/A & HKCRP unpublished \\
\hline 1 Mar 2003 & Stranding & T. truncatus & Tung Lung Chau & $\mathrm{F}$ & 219 & Hung 2003 \\
\hline 16 Aug 2004 & Stranding & T. aduncus & Chik Mun & $\mathrm{F}$ & 250 & Hung 2005b \\
\hline
\end{tabular}

U, unknown.

\section{Spinner dolphin Stenella longirostris (Gray, 1828)}

Two strandings of this species have been confirmed in Hong Kong, one on 5 August 1997 (ca. $186 \mathrm{~cm}$ ) and another on 17 August 1999 (184 cm) (AFCD records). In

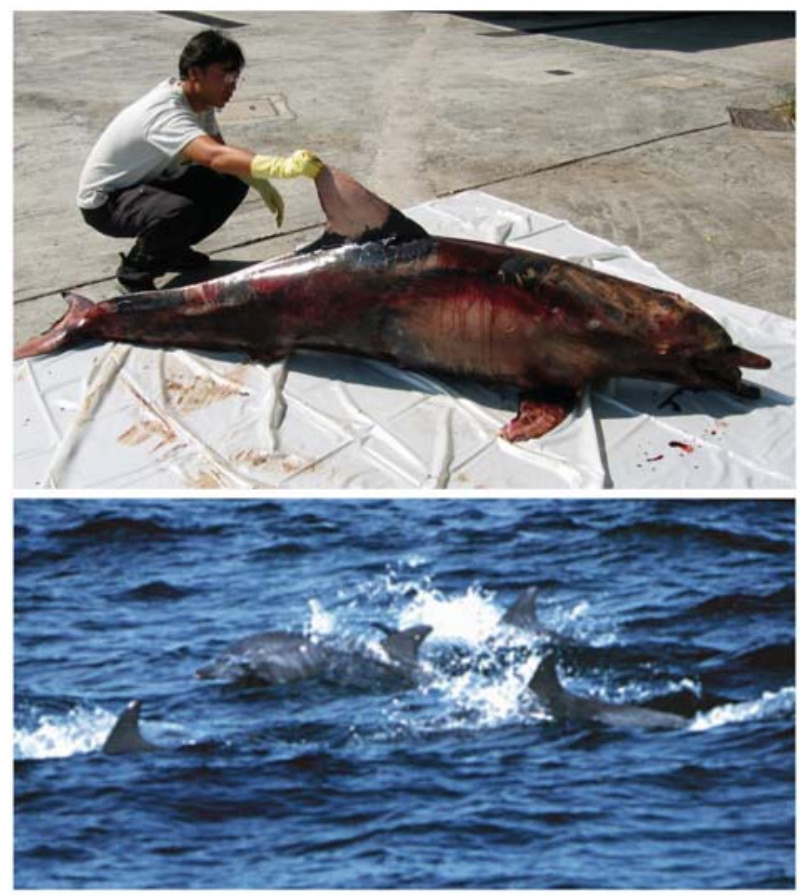

Figure 6 Indo-Pacific bottlenose dolphin stranding that occurred on 16 August 2004, the first confirmed record for this species in Hong Kong (top) and sighting of a group of probable Indo-Pacific bottlenose dolphins on 5 November 1998 near Po Toi Island (bottom). addition, a sighting of a single young animal in the eastern waters of Sai Kung was recorded in 1995 (Jefferson, unpublished data, also mentioned in Parsons et al. 1995). The latter animal was clearly lost or sick/injured, but no subsequent stranding was reported from this very sparsely populated part of Hong Kong.

\section{Striped dolphin Stenella coeruloealba (Meyen, 1833)}

Striped dolphins have been stranded in Hong Kong on five occasions. The first four events occurred in 1988, 1989, 1992 and 1994, and were reported by Parsons et al. (1995), while the most recent was on 6 August 1996 (AFCD records). The latter animal was a $220-\mathrm{cm}$ female washed ashore at Shek $\mathrm{O}$ on Hong Kong Island. No sightings of this species have been reported in or around Hong Kong.

\section{Long-beaked common dolphin Delphinus capensis}

The first report of a dolphin stranding in Hong Kong occurred in December 1954, with the animal reported to be a common dolphin Delphinus delphis (Romer 1958). The stuffed carcass of this animal, approximately $198 \mathrm{~cm}$ long, was shown in the paper and was exhibited by the University of Hong Kong for some time (Romer 1958). Unfortunately, the identification cannot be confirmed from the photo and the specimen was subsequently lost. We therefore consider this an unidentified dolphin.

The first confirmed stranding record of the longbeaked common dolphin from Hong Kong was obtained on 3 May 1989. This was a 183-cm male specimen livestranded at Chi Ma Wan, Lantau Island (Parsons et al. 1995, Plate 2). A second stranding (a mummified partial 
carcass) occurred on 8 August 1997 on Lamma Island. A third stranding occurred on 3 June 2000 of a specimen of $>208 \mathrm{~cm}$ and unknown sex stranded at Tai Long Wan (AFCD records). Finally, a dolphin of the genus Delphinus (species not yet confirmed) was entangled in a fishing net offshore of Po Toi Island on 16 May 2004 (Hung 2005a). Based on the known distribution patterns of the two known species in the genus (Jefferson and Van Waerebeek 2002), we suspect that all of these are examples of $D$. capensis tropicalis.

It should be noted that several sightings of this species, confirmed through photographic or video evidence, have been made in Hong Kong waters. The first occurred on 20 February 1978 and involved a group that made its way into Victoria Harbor (Figure 7; Parsons et al. 1995). Other sightings occurred in 1996 (on 13 January near Steep Island and on 7 March near Double Haven). We believe that the winter 1982/83 sighting of the dolphin group that was reported to be Pacific white-sided dolphins (Lagenorhynchus obliquidens) by Hammond and Leatherwood (1984) inside the harbor was probably a group of common dolphins. Finally, a lone juvenile of this species was sighted on 26 February 2006 in Sai Wan Ho, and another sighting of what was probably the same animal occurred near Aberdeen 3 months later (Figure 7; HKCRP, unpublished data).

\section{Fraser's dolphin Lagenodelphis hosei Fraser, 1956}

Only a single Fraser's dolphin record exists for Hong Kong. This was a stranding of a freshly dead $220-\mathrm{cm}$

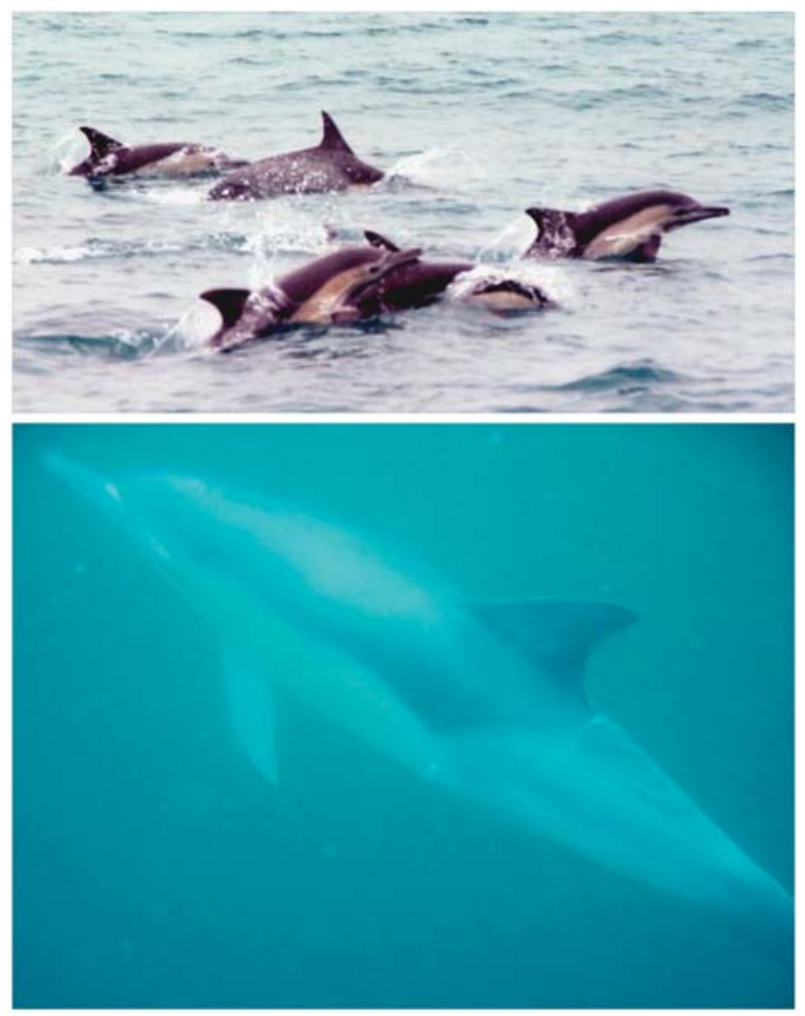

Figure 7 Group of long-beaked common dolphins that swam into Victoria Harbor in February 1978 (top, photo by Grant Abel) and a common dolphin sighted on 26 February 2006 in Sai Wan Ho (bottom).

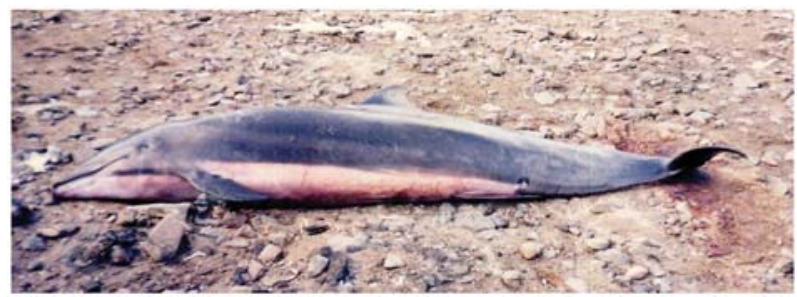

Figure 8 Fraser's dolphin stranding that occurred 31 May 1995 (photo by L.J. Porter, courtesy of AFCD).

male at Plover Cove in Tolo Channel on 31 May 1995 (Figure 8; Parsons et al. 1995). The species has not been sighted in waters in or immediately adjacent to Hong Kong, and probably occurs far offshore in this area.

\section{Finless porpoise Neophocaena phocaenoides} (G. Cuvier, 1829)

There is only one species of the family Phocoenidae in this part of the world, the finless porpoise. The finless porpoise is the most commonly stranded species of marine mammal in Hong Kong (Parsons et al. 1995, Parsons 1998c, Jefferson et al. 2002a), with an average of 11 strandings per year (Jefferson et al. 2006). They are not as commonly sighted as Indo-Pacific humpback dolphins, mostly because of their more cryptic appearance and behavior. They are common in winter and spring months in the waters of southern and eastern Hong Kong that are not affected by the Pearl River outflow, but are somewhat less commonly observed in summer and autumn (Parsons 1998b, Jefferson et al. 2002b). Their abundance in Hong Kong waters ranges from a high of approximately 152 individuals in spring to approximately 55 in autumn (Jefferson et al. 2002b). Other than an occasional stranding, finless porpoises do not occur in Hong Kong's northwestern waters.

\section{Dugong Dugong dugon Lacépéde, 1799}

This is the only representative of the order Sirenia that occurs in the South China Sea. The dugong does not occur at present in Hong Kong, but there is some evidence to suggest that it may have occurred there in the past. G. Herklotz supposedly saw one specimen brought to the city in 1940 or 1941 (Bertram and Bertram 1973). However, it was not stated how the animal was identified or where it was secured. A small population of dugongs may still persist in Hainan and Guangxi Provinces near Hainan Island (Marsh et al. 2002, Zhou et al. 2003), but there is no reason to expect them to move as far northeast as Hong Kong. Speculations that dugongs may once have inhabited the Pearl River Estuary (Porter 1998) are not supported by any concrete evidence, but are plausible, as dugongs are known to use estuaries for calving (Marsh et al. 2002). Seagrass habitats were available on Lantau Island (near Tung Chung), thereby providing a potential food source for dugongs, until the new airport construction destroyed them in the 1990s (Fong 1999). 


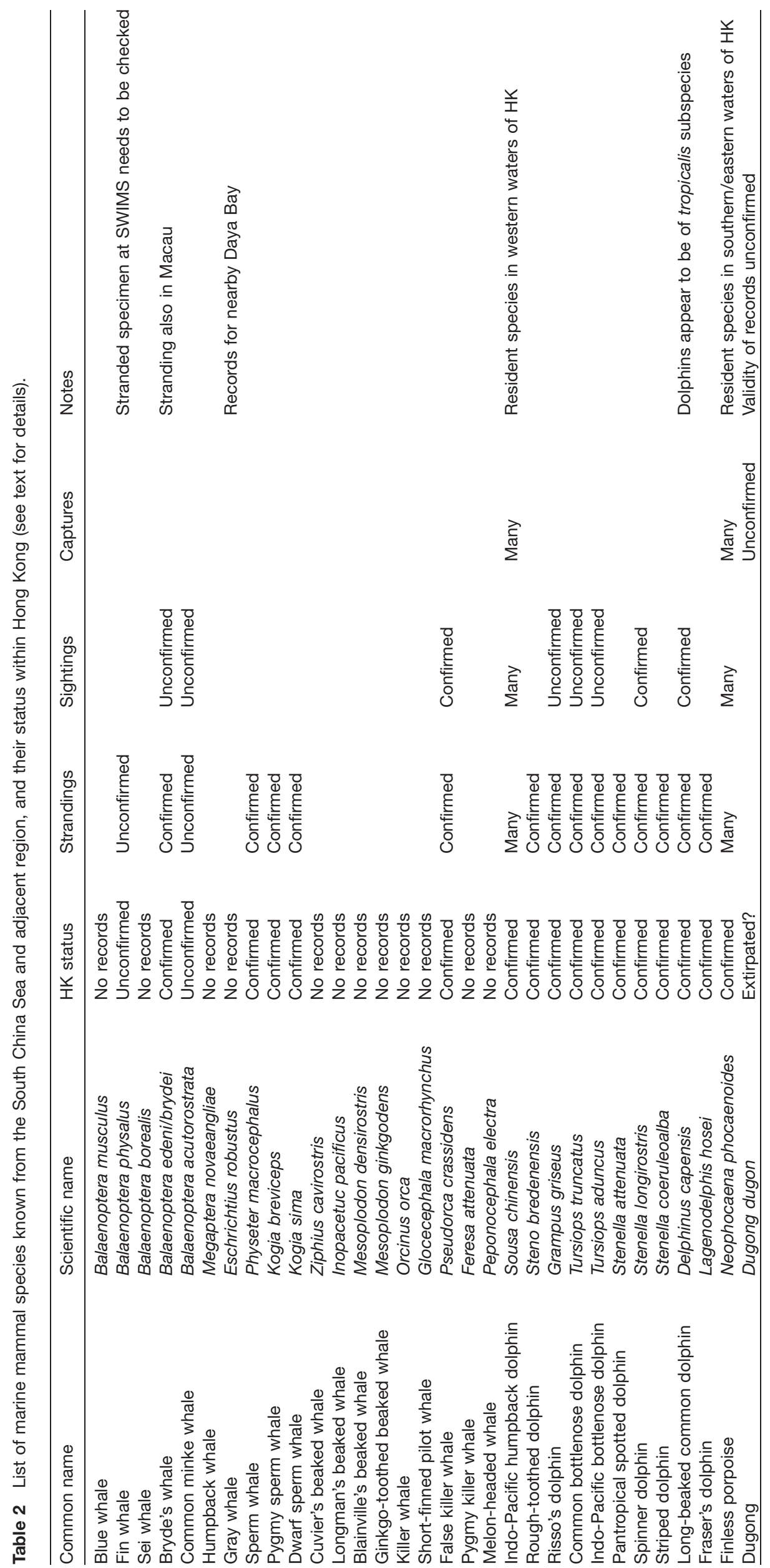




\section{Discussion}

After updating and correcting some errors in older data records, we have now been able to confirm 16 species of cetaceans from Hong Kong. An additional two cetacean species have been reported from Hong Kong, but have not yet been confirmed (owing to uncertainties in the initial identifications). There are a number of other species that might be expected to occur in Hong Kong based on distribution patterns in the surrounding areas of the South China Sea (Table 2). Some of these other species will almost definitely be found to occur in Hong Kong in the future (e.g., one or more species of beaked whales, the killer whale, short-finned pilot whale, pygmy killer whale, and melon-headed whale). Others are known from the western North Pacific, but probably do not occur in the South China Sea (e.g., the North Pacific right whale and the short-beaked common dolphin). Still other marine mammals may have occurred there historically, but have probably been extirpated from the area by anthropogenic population pressures (e.g., gray whale and dugong).

The case of the gray whale is interesting. Although the California (eastern North Pacific) stock of the gray whale has recovered from heavy whaling in the past several centuries and is now numerous, the Korean (western North Pacific) stock has not recovered. It is currently thought to number only about 100 individuals, and little is known about where animals from this stock migrate to in the winter for breeding (Weller et al. 2002). Records and historical accounts of gray whales from southern China (including Daya Bay, immediately to the east of Hong Kong's Mirs Bay) suggest that western gray whales may once have used the waters of Guangdong and Guangxi Provinces for breeding (Wang 1984). However, no sightings have been recorded from these areas in recent years. Whether this is simply a result of the very low abundance of the species, or whether these areas are no longer used, is unknown. However, if this population recovers under current protection and dedicated conservation efforts (Weller et al. 2002), it will be interesting to see if western gray whales begin to show up in or near Hong Kong. There is even some evidence that humpback whales may have been caught in Daya Bay in the past (Wang 1999). Several "Tin Hau" (goddess of the sea) temples in Hong Kong contain whale bones, although to our knowledge these have not yet been analyzed to determine their specific identity.

A total of 31 species of marine mammals ( 7 baleen whales, 23 toothed whales, and 1 sirenian; Table 2) have been confirmed to occur in the South China Sea and immediately adjacent waters (Zhou et al. 1995, Wang et al. 2001, MacLeod et al. 2006, Wang and Yang 2006, Jefferson et al. in press). More than half of these (16 species, $52 \%$ ) have been confirmed to occur in Hong Kong, and it is likely that additional species will be confirmed to occur there in the future. Despite the fact that many of these do not occur regularly in the nearshore waters within Hong Kong's boundaries and are probably little more than occasional visitors to Hong Kong, this is a fairly large number of species for such a small place.
There is still much uncertainty about the distribution and habitat preferences, and even such basics as the occurrence patterns, of marine mammal species that occur in the offshore South China Sea. For instance, the recently described Omura's whale (Balaenoptera omurai) is known from the area to the east of the South China Sea (Wada et al. 2003, Sasaki et al. 2006) and it appears likely that the species may occur in the South China Sea, and perhaps even offshore of Hong Kong. However, until large-scale marine mammal surveys have been undertaken in the offshore South China Sea our knowledge will remain sparse. This is a need that should be addressed in the near future.

One point that is clear is that only two species of marine mammals (the humpback dolphin and finless porpoise) occur in Hong Kong on a regular basis (i.e., are "resident" species). Some of the other species that have been identified from the area probably normally occur offshore of Hong Kong, along the adjacent continental shelf and make their way into Hong Kong waters now and then during the course of their normal movements (e.g., Bryde's whale, false killer whale, both species of bottlenose dolphins, and long-beaked common dolphin). Finally, there are species that normally occur in deep, oceanic waters beyond the continental shelf break and presumably only arrive in Hong Kong when lost or sick/ injured (e.g., the sperm whale, both species of Kogia, striped dolphin, and Fraser's dolphin). Only future monitoring of strandings and sightings will clarify whether these presumed patterns are indeed accurate.

\section{Acknowledgements}

We would like to thank World Wildlife Fund Hong Kong and the Agriculture, Fisheries and Conservation Department of the Hong Kong Government for having the foresight to begin documenting and collecting information on marine mammal strandings in Hong Kong in the 1970s. Special thanks are extended to our current colleagues within AFCD, Joseph Sham, Ivan Chan, and Wong Fook-Yee, for their support over the past few years. In addition, many people helped with collecting information in the past, in particular I. Beasley, W. Cheng, K. Cheung, C. Choi, D. Choi, R. Kinoshita, S. Leatherwood, A. Lee, J. Lun, S. Ng, E.C.M. Parsons, L.J. Porter, M. Torey, J.Y. Wang, D. Wong, and L. Yeung. Our research in Hong Kong over the past 12 years has largely been supported by the AFCD, the Ocean Park Conservation Foundation, and the Hong Kong Dolphin Conservation Society. The manuscript was improved by suggestions from E.C.M. Parsons and an anonymous reviewer.

\section{References}

Barros, N.B., E.C.M. Parsons and T.A. Jefferson. 2000. Prey of offshore bottlenose dolphins from the South China Sea. Aquat. Mamm. 26: 2-6.

Bertram, G.C.L. and C.K.R. Bertram. 1973. The modern Sirenia: their distribution and status. Biol. J. Linn. Soc. 5: 297-338.

Dizon, A.E., C.A. Lux, R.G. LeDuc, J. Urban R., M. Henshaw, C.S. Baker, F. Cipriano and R.L. Brownell. 1996. Molecular phylogeny of the Bryde's/sei whale complex: separate species status for the pygmy Bryde's form? International Whaling Commission, Research Paper SC/48/O27 (unpublished). 
Fong, T.C.W. 1999. Conservation and management of Hong Kong seagrasses. Asian Mar. Biol. 16: 109-121.

Hammond, D.D. and S. Leatherwood. 1984. Cetaceans live-captured for Ocean Park, Hong Kong April 1974-February 1983. Rep. Int. Whal. Commission 34: 491-496.

Hong Kong Dolphinwatch. 1996. Whales sighted! The Dolphinwatcher 3: 1.

Hung, S.K. 2001. Bryde's whale stranding in Macau. Hong Kong Discovery Mag. 2: 29-32.

Hung, S.K. 2003. Monitoring of Chinese white dolphins (Sousa chinensis) in Hong Kong waters - data collection: final report (2002-03). Unpublished report to the Hong Kong Agriculture, Fisheries and Conservation Department. $74 \mathrm{pp}$.

Hung, S.K. 2004. Monitoring of Chinese white dolphins (Sousa chinensis) in Hong Kong waters - data collection: final report (2003-04). Unpublished report to the Hong Kong Agriculture, Fisheries and Conservation Department. 87 pp.

Hung, S.K. 2005a. Monitoring of Chinese white dolphins (Sousa chinensis) in Hong Kong waters - data collection: final report (2004-05). Unpublished report to the Hong Kong Agriculture, Fisheries and Conservation Department. 107 pp.

Hung, S.K. 2005b. Monitoring of finless porpoise (Neophocaena phocaenoides) in Hong Kong waters - data collection: final report (2003-05). Unpublished report to the Hong Kong Agriculture, Fisheries and Conservation Department. 95 pp.

Hung, S.K. 2006. Monitoring of Chinese white dolphins (Sousa chinensis) in Hong Kong waters - data collection: final report (2005-06). Unpublished report to the Hong Kong Agriculture, Fisheries and Conservation Department. $116 \mathrm{pp}$.

Hung, S.K. and T.A. Jefferson. 2001. Records of Bryde's whales (Balaenoptera c.f. edeni) along the coast of China, with notes on two animals recently stranded in Hong Kong and Macau. Paper presented at the 14th Biennial Conference on the Biology of Marine Mammals, Vancouver, BC, Canada (unpublished).

Hung, S.K. and T.A. Jefferson. 2004. Ranging patterns of IndoPacific humpback dolphins (Sousa chinensis) in the Pearl River Estuary, People's Republic of China. Aquat. Mamm. 30: 159-174.

Jefferson, T.A. 2000. Population biology of the Indo-Pacific hump-backed dolphin in Hong Kong waters. Wildl. Monogr. 144: $65 \mathrm{pp}$.

Jefferson, T.A. and S.K. Hung. 2004. A review of the status of the Indo-Pacific humpback dolphin (Sousa chinensis) in Chinese waters. Aquat. Mamm. 30: 149-158.

Jefferson, T.A. and S. Leatherwood. 1997. Distribution and abundance of Indo-Pacific hump-backed dolphins (Sousa chinensis Osbeck, 1765) in Hong Kong waters. Asian Mar. Biol. 14: 93-110.

Jefferson, T.A. and K. Van Waerebeek. 2002. The taxonomic status of the nominal dolphin species Delphinus tropicalis van Bree, 1971. Mar. Mamm. Sci. 18: 787-818.

Jefferson, T.A., B.E. Curry and R. Kinoshita. 2002a. Mortality and morbidity of Hong Kong finless porpoises, with emphasis on the role of environmental contaminants. Raffles Bull. Zool. Suppl. 10: 161-171.

Jefferson, T.A., S.K. Hung, L. Law, M. Torey and N. Tregenza. 2002b. Distribution and abundance of finless porpoises in Hong Kong and adjacent waters of China. Raffles Bull. Zool. Suppl. 10: 43-55.

Jefferson, T.A., K.M. Robertson and J.Y. Wang. 2002c. Growth and reproduction of the finless porpoise in southern China. Raffles Bull. Zool. Suppl. 10: 105-113.

Jefferson, T.A., S.K. Hung and Y.S. Qui. 2005. The Indo-Pacific humpback dolphin population in the Pearl River Estuary: population size and trends. In: (T.A. Jefferson, ed.) Monitoring of Indo-Pacific humpback dolphins (Sousa chinensis) in Hong Kong waters - data analysis: final report. Final contract report to the Agriculture, Fisheries and Conservation Department, Hong Kong Government. pp. 2.1-2.40.
Jefferson, T.A., S.K. Hung and P.K.S. Lam. 2006. Strandings, mortality and morbidity of Indo-Pacific humpback dolphins in Hong Kong, with emphasis on the role of organochlorine contaminants. J. Cetacean Res. Manage. 8: 181-193.

Jefferson, T.A., M.A. Webber and R.L. Pitman. In press. Marine mammals of the world: a comprehensive guide to their identification. Academic Press/Elsevier, London.

LeDuc, R.G. and A.E. Dizon. 2002. Reconstructing the rorqual phylogeny: with comments on the use molecular and morphological data for systematic study. In: (C.J. Pfeiffer, ed.) Molecular and cell biology of marine mammals. Krieger Publishing Company, New York. pp. 100-110.

MacLeod, C.D., W.F. Perrin, R.L. Pitman, J. Barlow, L. Ballance, A. d'Amico, T. Gerrodette, G. Joyce, K.D. Mullin, D.L. Palka and G.T. Waring. 2006. Known and inferred distributions of beaked whale species (Ziphiidae: Cetacea). J. Cetacean Res. Manage. 7: 271-286.

Marsh, H., H. Penrose, C. Eros and J. Hughes. 2002. Dugong: status report and action plans for countries and territories. UNEP Early Warning and Assessment Report Series. 155 pp.

Morton, B., A.J. Bentham, J.W. Bradford and P.T.T. Kou. 1992. The reconstruction of "Hong Kong's whale" (Balaenoptera physalus). Asian Mar. Biol. 9: 235-243.

Parsons, E.C.M. 1997. Hong Kong's cetaceans: The biology, ecology and behaviour of Sousa chinensis and Neophocaena phocaenoides. Ph.D. thesis, University of Hong Kong.

Parsons, E.C.M. 1998a. Trace metal pollution in Hong Kong: implications for the health of Hong Kong's Indo-Pacific hump-backed dolphins (Sousa chinensis). Sci. Total Environ. 214: 175-184.

Parsons, E.C.M. 1998b. The behaviour of Hong Kong's resident cetaceans: the Indo-Pacific hump-backed dolphin and the finless porpoise. Aquat. Mamm. 24: 91-110.

Parsons, E.C.M. 1998c. Strandings of small cetaceans in Hong Kong territorial waters. J. Mar. Biol. Assoc. UK 78: 10391042.

Parsons, E.C.M. 1999. Trace element concentrations in the tissues of cetaceans from Hong Kong's territorial waters. Environ. Conserv. 26: 30-40.

Parsons, E.C.M. and H.M. Chan. 1998. Organochlorines in IndoPacific hump-backed dolphins (Sousa chinensis) and finless porpoises (Neophocaena phocaenoides) from Hong Kong. In: (B. Morton, ed.) The marine biology of the South China Sea III. Hong Kong University Press, Hong Kong. pp. 423-437.

Parsons, E.C.M. and H.M. Chan. 2001. Organochlorine and trace element contamination in bottlenose dolphins (Tursiops truncatus) from the South China Sea. Mar. Pollut. Bull. 42: 780-786.

Parsons, E.C.M. and T.A. Jefferson. 2000. Post-mortem investigations on stranded dolphins and porpoises from Hong Kong waters. J. Wildl. Dis. 36: 342-356.

Parsons, E.C.M., H.M. Chan and R. Kinoshita. 1999. Trace metal and organochlorine concentrations in a pygmy Bryde's whale (Balaenoptera edeni) from the South China Sea. Mar. Pollut. Bull. 38: 51-55.

Parsons, E.C.M., M.L. Felley and L.J. Porter. 1995. An annotated checklist of cetaceans recorded from Hong Kong's territorial waters. Asian Mar. Biol. 12: 79-100.

Porter, L.J. 1998. The taxonomy, ecology and conservation of Sousa chinensis (Osbeck, 1765) (Cetacea: Delphinidae) in Hong Kong waters. Ph.D. thesis, University of Hong Kong.

Porter, L. and B. Morton. 2003. A description of the first intact dwarf sperm whale from the South China Sea and a review of documented specimens of the Kogiidae (Cetacea) from Hong Kong. Syst. Biodivers. 1: 127-135.

Reeves, R.R., W.F. Perrin, B.L. Taylor, C.S. Baker and S.L. Mesnick. 2004. Report of the Workshop on Shortcomings of Cetacean Taxonomy in Relation to Needs of Conservation and Management, April 30-May 2, 2004, La Jolla, CA. NOAA Technical Memorandum NMFS-SWFSC 363. 94 pp.

Romer, J.D. 1958. Cetaceans recorded from within or near Hong Kong territorial waters. Hong Kong Univ. Fish. J. 2: 127-129. 
Sasaki, T., M. Nikaido, S. Wada, T.K. Yamada, Y. Cao, M. Hasegawa and N. Okada. 2006. Balaenoptera omurai is a newly discovered baleen whale that represents an ancient evolutionary lineage. Mol. Phylogenet. Evol. 41: 40-52.

Torey, M. 2000. Study on interactions between cetaceans and fisheries in Hong Kong waters: final report. Report to the Ocean Park Conservation Foundation (unpublished).

Wada, S., M. Oishi and T. Yamada. 2003. A newly discovered species of living baleen whale. Nature 426: 278-281.

Wang, J.Y. and S.C. Yang. 2006. Unusual cetacean stranding events of Taiwan in 2004 and 2005. J. Cetacean. Res. Manage. 8: 283-292.

Wang, J.Y., S.C. Yang and H.C. Liao. 2001. Species composition, distribution and relative abundance of cetaceans in the waters of southern Taiwan: implications for conservation and eco-tourism. J. Natl. Parks Taiwan 11: 136-158.
Wang, P. 1984. [Distribution of the gray whale (Eschrichtius gibbosus) off the coast of China]. Acta Theriol. Sin. 4: 21-26 (in Chinese, translated by Hiedi Chan).

Wang, P. 1999. [Chinese cetaceans]. Ocean Enterprises Ltd., Hong Kong (in Chinese).

Weller, D.W., A.M. Burdin, B. Würsig, B.L. Taylor and R.L. Brownell Jr. 2002. The western gray whale: a review of past exploitation, current status and potential threats. J. Cetacean Res. Manage. 4: 7-12.

Zhou, K., S. Leatherwood and T.A. Jefferson. 1995. Records of small cetaceans in Chinese waters: a review. Asian Mar. Biol. 12: 119-139.

Zhou, K., X. Xu and J. Tang. 2003. Survey of the status of the dugong in the Beibu Gulf, China, with remarks on the Indian humpbacked dolphin (Sousa plumbea). Acta Theriol. Sin. 23: 21-26 (in Chinese, with English summary). 